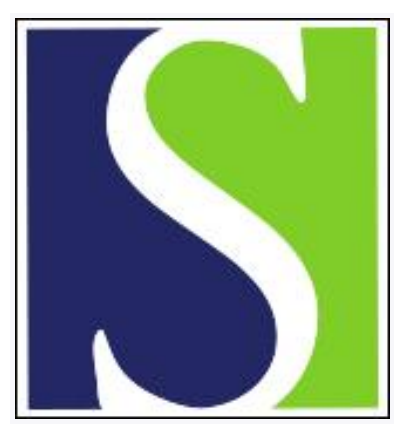

Scand J Work Environ Health 1997;23(4):266-270

https://doi.org/10.5271/sjweh.219

Issue date: Aug 1997

Trends in mesothelioma incidence and occupational mesotheliomas in Finland in 1960--1995

by Karjalainen A, Pukkala E, Mattson K, Tammilehto L, Vainio H

Key terms: anthophyllite; chrysotile; crocidolite; incidence; mesothelioma; occupational mesothelioma

This article in PubMed: www.ncbi.nlm.nih.gov/pubmed/9322817

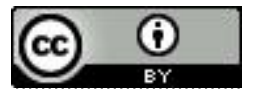




\title{
Trends in mesothelioma incidence and occupational mesotheliomas in Finland in 1960-1995
}

\author{
by Antti Karjalainen, MD, Eero Pukkala, PhD, ${ }^{1}$ Karin Mattson, MD, ${ }^{3}$ Lauri Tammilehto, MD, ${ }^{1}$ \\ Harri Vainio, $M D^{4}$
}

\begin{abstract}
Karjalainen A, Pukkala E, Mattson K, Tammilehto L, Vainio H. Trends in mesothelioma incidence and occupational mesotheliomas in Finland in 1960-1995. Scand J Work Environ Health 1997;23(4):266-70.

Objectives The study analyzed the recent trend in the incidence of mesothelioma in Finland and evaluated the coverage of reporting work-related mesothelioma.

Methods The incidence of mesothelioma in 1960-1995 was retrieved from the Finnish Cancer Registry, and the number of asbestos-associated work-related mesotheliomas were taken from the Finnish Register of Occupational Diseases.

Results The annual number of mesotheliomas increased rapidly in 1975 - 1990. In the 1990s, the age-adjusted incidence remained relatively stable for Finnish men. The annual number of cases still increased among men over 65 years of age, but decreased slightly among men under 55 years of age and among women. About 35 annual cases were diagnosed among men and 10-15 among women in the mid-1990s. The reporting of workrelated mesotheliomas improved during the Finnish asbestos program in 1987-1992. In 1993-1995 about 30 annual cases (ie, about $90 \%$ of all pleural and $50 \%$ of the peritoneal mesotheliomas in men) were reported to be work-related.

Conclusions The increasing trend in the incidence of mesothelioma in Finland has slowed down in the 1990s, and the maximum of asbestos-related cases in the early 2000 s will probably be clearly less than the 100 annual cases estimated in the early 1990s. If the observed trend continues up to 2010, about 40-50 cases among men and 10-20 among women will then be diagnosed annually. Altogether $40-50$ of these cases would be related to occupational asbestos exposure.
\end{abstract}

Key terms anthophyllite, chrysotile, crocidolite, incidence, mesothelioma, occupational.

Mesothelioma is closely related to past exposure to asbestos, but the etiologic fraction due to asbestos varies between geographic areas. A recent analysis in North America suggested that, for men, $88 \%$ of pleural and $58 \%$ of peritoneal mesotheliomas and, for women, $23 \%$ of mesotheliomas are attributable to past exposure to asbestos (1). A background incidence of $1-2$ cases per million per year without asbestos exposure has been proposed (2). Genetic and exogenous modifiers of the asbestos-associated risk may exist $(3,4)$. The typical latency time from first exposure to disease is $30-40$ years, and the incidence of mesothelioma has rapidly increased during the past few decades in most industrialized countries. In some areas the increase seems to have leveledoff in the 1990s (5-8). A more pessimistic projection has, however, been published for Great Britain (9). In Finland it has been estimated that the incidence of mesothelioma would peak around 2010 with about 100 annual asbestos-related cases in a population of 5 million (10).

Asbestos-related diseases have been subject to much public concern, and consequently patients and physicians are today better aware of the role of asbestos in the etiology of mesothelioma. Yet, mesothelioma is still underreported as an occupational cancer in Sweden and Denmark $(11,12)$. In Finland, a nationwide campaign was undertaken to improve the diagnostics of asbestosrelated diseases during the asbestos program in 1987 1992 (13).

The objectives of our study were to investigate (i) whether the recent trend in the incidence of mesothelio-

1 Finnish Institute of Occupational Health, Helsinki, Finland.

2 Finnish Cancer Registry, Helsinki, Finland.

3 Helsinki University Central Hospital, Helsinki, Finland.

4 International Agency for Research on Cancer, Lyon, France.

Reprint requests to: Dr Antti Karjalainen, Finnish Institute of Occupational Health, Topeliuksenkatu 41 A a, FIN-00250 Helsinki, Finland. 
ma in Finland indicates a need to reevaluate previous projections for the early 2000s and (ii) whether mesothelioma is still underreported as an occupational cancer in Finland.

\section{Subjects and methods}

The annual number of pleural and peritoneal mesotheliomas reported to the Finnish Cancer Registry in 19601995 was calculated for men and women in different age categories. As the diagnosis of mesothelioma is sometimes difficult, the numbers of other primary pleural cancers and their histological diagnoses were analyzed separately. The numbers of asbestos-associated work-related mesotheliomas were retrieved from the Finnish Register of Occupational Diseases. The trend in the reporting of mesothelioma as an occupational disease was analyzed by comparing the annual statistics of the Finnish Register of Occupational Diseases and the Finnish Cancer Registry. The cases were not compared at the individual level. As the annual numbers were low, the 3 -year means are usually given. Age-adjusted incidence rates were adjusted to the world standard population.

All hospitals, medical practitioners, and institutions with hospital beds are obliged to notify the Finnish Cancer Registry about all cancer cases that come to their attention. Moreover, the Registry receives information on specimens with a diagnosis of cancer from pathology laboratories and also information on death certificates from Statistics Finland whenever cancer is mentioned. An average of 5 notifications per case is received during the course of the disease. This cancer registration system is virtually complete (14). Reporting of all known or suspected occupational diseases to provincial labor protection authorities is compulsory for Finnish physicians.
In addition to the reports forwarded by the labor protection authorities, the Finnish Register of Occupational Diseases receives notifications of every new case reported as an occupational disease to the insurance companies, regardless of the compensation decision. Information from these 2 sources is combined so that each case of permanent work-related disease is recorded only once.

\section{Results}

The annual number of mesotheliomas rose steeply in 1975-1990, but it has not increased in the 1990s (figure 1). So far the highest annual number was recorded in 1989, when 57 new cases were diagnosed ( 31 for men, 26 for women). For men the annual number of cases rose from about 7 in 1975 to about 30 in 1985 and to about 35 in 1995. For women the annual number of cases increased in 1975-1990, but fell thereafter to about 10 per year.

From 1985 - 1989 to 1990 - 1995, the annual number of mesotheliomas decreased slightly among men under 55 years of age but increased clearly among men over 65 years of age (figure 2). The age-adjusted incidence for men has remained relatively stable since the mid1980s (figure 3). In 1990-1994 the age-adjusted incidence was 10 per million person-years for men and 2.9 for women.

The annual number of primary pleural cancers other than mesothelioma has always been small and did not change markedly in 1985-1995. In 1985-1989 there were about 8 annual cases among men and 4 among women, and, in 1990-1994, 9 and 5 annual cases were reported, respectively. Most of them were cases with no specific histology, but also some adenocarcinomas were reported for men (table 1).
Figure 1. Use of asbestos and the annual number of mesotheliomas (3-year moving average) in Finland 1960-1995.

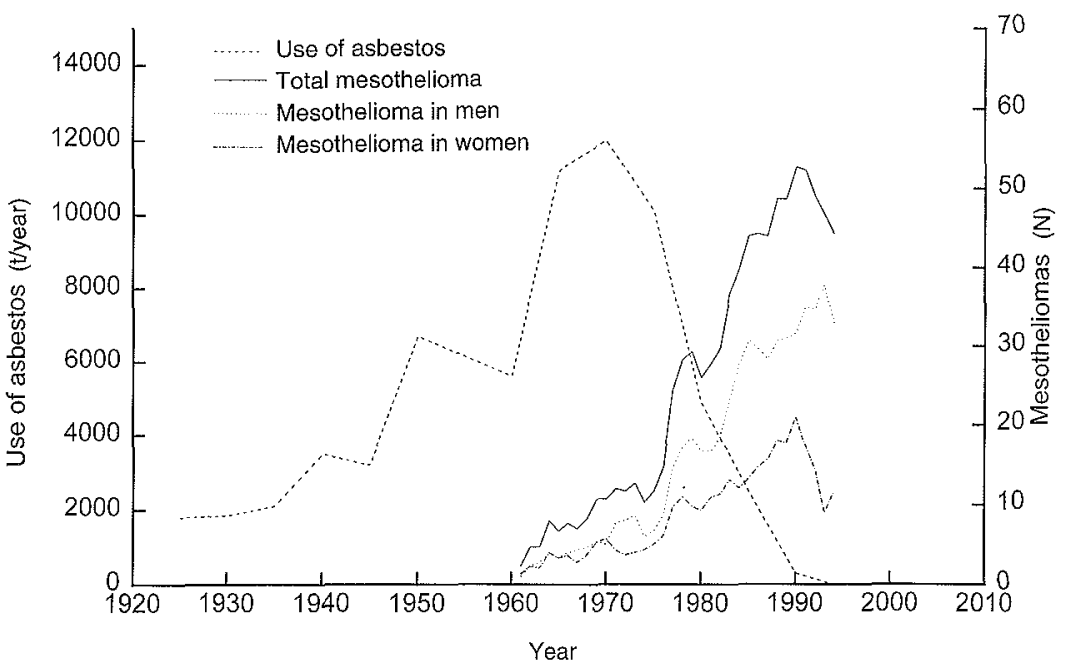

Scand J Work Environ Health 1997, vol 23, no 4 

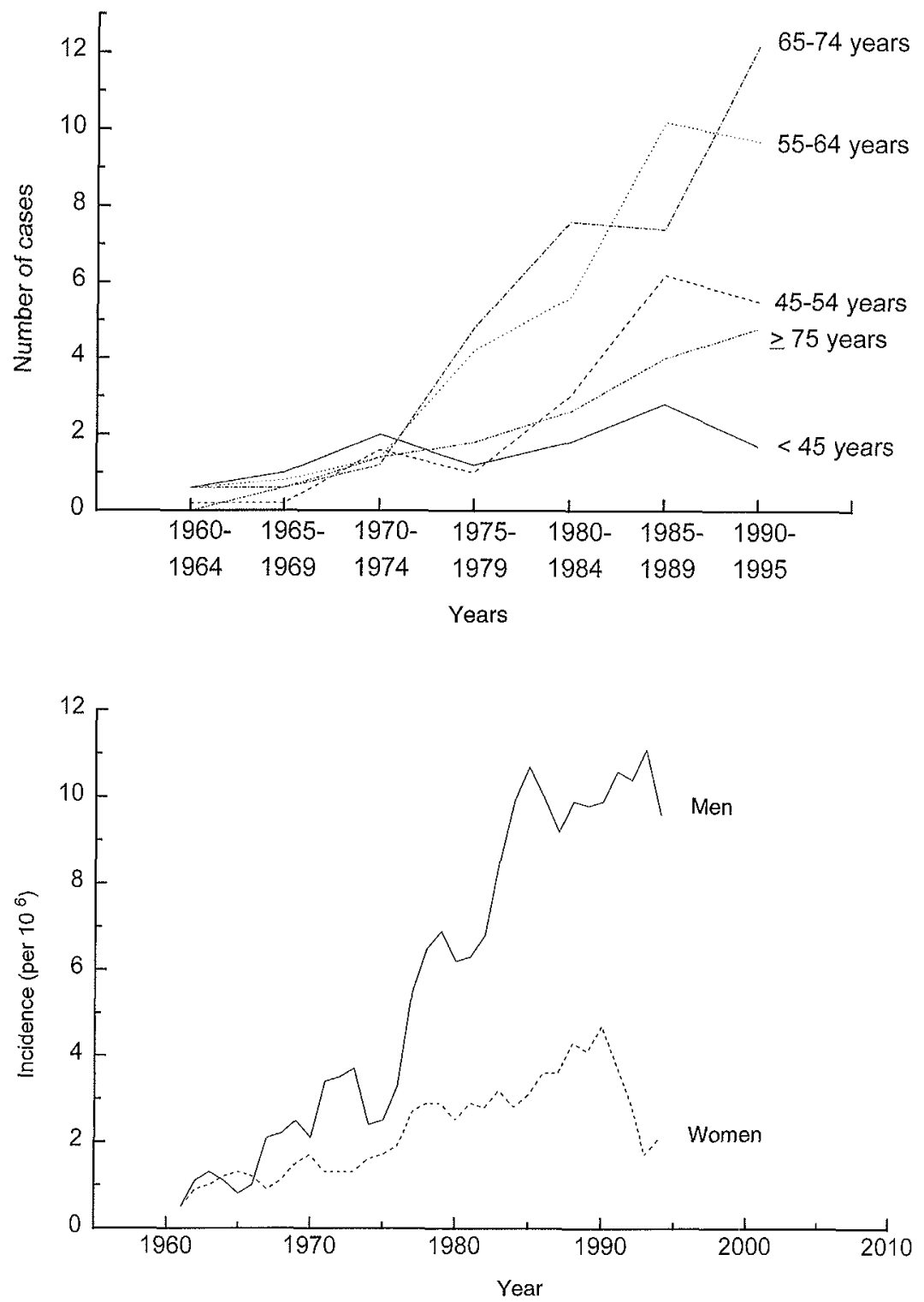

Figure 2. Annual numbers of mesotheliomas in men in Finland by age group in 1960-1995.
Table 1. Primary pleural cancers recorded in the Finnish Cancer Registry in 1990-1994.

\begin{tabular}{lrrrrr}
\hline \multirow{2}{*}{ Diagnosis } & \multicolumn{2}{c}{ Men } & & \multicolumn{2}{c}{ Women } \\
\cline { 2 - 3 } \cline { 6 - 7 } & $N$ & $\%$ & & $N$ & $\%$ \\
\hline Mesothelioma & 154 & 77 & & 51 & 74 \\
Adenocarcinoma & 10 & 5 & & - & 0 \\
Squamous-cell carcinoma & 2 & 1 & & - & 0 \\
Sarcoma & 2 & 1 & & - & 0 \\
Unspecified carcinoma & - & 0 & & 2 & 3 \\
Controversial histology & 2 & 1 & & 1 & 1 \\
Unknown histology & 8 & 4 & & 4 & 6 \\
No histology & 22 & 11 & & 11 & 16 \\
\hline Total & 200 & 100 & & 69 & 100 \\
\hline
\end{tabular}

Only occasional work-related mesotheliomas were notified to the Finnish Register of Occupational Diseases before the mid-1980s. The number of cases started to increase in the late 1980 s and still increased in the 1990s (table 2). About 30 annual cases were reported in 1993-1995. During the same period the number of work-related pleural mesotheliomas in men was $90 \%$ of that reported to the Finnish Cancer Registry (table 2). The proportion of reported work-related cases was lower for peritoneal mesotheliomas and for mesotheliomas in women.

Figure 3. Age-adjusted incidence of mesothelioma in Finland (3-year moving average). 
Table 2. Mesothelioma cases listed for men and women in the Finnish Cancer Registry and the Finnish Register of Occupational Diseases in 1984-1995 and the proportion of work-related cases (\%).

\begin{tabular}{|c|c|c|c|c|c|c|}
\hline \multirow[t]{2}{*}{ Period of time } & \multicolumn{3}{|c|}{ Men } & \multicolumn{3}{|c|}{ Women } \\
\hline & $\begin{array}{c}\text { Finnish Cancer } \\
\text { Registry }\end{array}$ & $\begin{array}{c}\text { Finnish Register } \\
\text { of Occupational } \\
\text { Diseases }\end{array}$ & $\begin{array}{c}\text { Proportion of } \\
\text { work-related } \\
\text { cases }(\%)\end{array}$ & $\begin{array}{c}\text { Finnish Cancer } \\
\text { Registry }\end{array}$ & $\begin{array}{c}\text { Finnish Register } \\
\text { of Occupational } \\
\text { Diseases }\end{array}$ & $\begin{array}{c}\text { Proportion of } \\
\text { work-related } \\
\text { cases }(\%)\end{array}$ \\
\hline \multicolumn{7}{|l|}{$1984-1986$} \\
\hline $\begin{array}{l}\text { Pleura }(\mathbb{N}) \\
\text { Peritoneum (N) }\end{array}$ & $\begin{array}{l}79 \\
13\end{array}$ & $\underline{9}$ & 11 & $\begin{array}{l}29 \\
11\end{array}$ & -1 & $\underline{3}$ \\
\hline \multicolumn{7}{|l|}{$1987-1989$} \\
\hline $\begin{array}{l}\text { Pleura (N) } \\
\text { Peritoneum (N) }\end{array}$ & $\begin{array}{l}81 \\
11\end{array}$ & 45 & $\underline{55}$ & $\begin{array}{l}43 \\
12\end{array}$ & -2 & -5 \\
\hline \multicolumn{7}{|l|}{$1990-1992$} \\
\hline $\begin{array}{l}\text { Pleura (N) } \\
\text { Peritoneum (N) }\end{array}$ & $\begin{array}{r}98 \\
7\end{array}$ & $\begin{array}{r}44 \\
2\end{array}$ & $\begin{array}{l}45 \\
29\end{array}$ & $\begin{array}{l}36 \\
16\end{array}$ & $\begin{array}{l}4 \\
1\end{array}$ & $\begin{array}{r}11 \\
6\end{array}$ \\
\hline \multicolumn{7}{|l|}{$1993-1995$} \\
\hline $\begin{array}{l}\text { Pleura (N) } \\
\text { Peritoneum (N) }\end{array}$ & $\begin{array}{l}89 \\
12\end{array}$ & $\begin{array}{r}80 \\
6\end{array}$ & $\begin{array}{l}90 \\
50\end{array}$ & $\begin{array}{r}25 \\
9\end{array}$ & -4 & $\frac{16}{-}$ \\
\hline
\end{tabular}

men or women. The low number of reported unspecified pleural malignancies indicates that the findings are not likely due to changes in diagnostic accuracy. If the trend observed in 1985-1995 continues up to 2010 , about $40-50$ annual mesotheliomas will then be detected among men and 10-20 among women. Probably altogether $40-50$ of them would be related to occupational exposure to asbestos. As the increase slowed down from $1975-1985$, it is possible that it will slow down even further. If so, the aforementioned estimates for the future would be reduced. A decreasing trend should first be observed in the birth cohorts which entered worklife when the most hazardous exposures had already peaked. The annual numbers for men under 55 years of age have decreased slightly in the 1990s. This observation is based, however, on a rather small annual number of cases.

There are 2 probable explanations for the apparent plateauing of the mesothelioma trend. The steepness of the increase in 1975-1985 was partly artificial and caused by improvement in the diagnostics of mesothelioma. The increase in the incidence had probably started already earlier. It is also probable that the occurrence of the most hazardous exposures did not increase as much as did the total use of asbestos in the 1960s. Crocidolite spraying decreased in Finland in the late 1960s and early 1970s and was banned in 1976. Most of the increase in the use of asbestos in the 1960s concerned asbestos cement products and other chrysotile-containing and less friable asbestos products. The mesothelioma risk associated with chrysotile asbestos is still controversial, but it is lower than that caused by crocidolite $(2,15,16)$.

While the increasing trend in the total incidence of mesothelioma seems to have slowed down, the reporting of occupational mesotheliomas clearly improved during the national asbestos program in 1987-1992. During the program a guidebook was published, and a nation- wide training and information campaign was undertaken to ensure systematic exposure assessment in all suspected cases of asbestos-related respiratory cancers (17). If the etiologic fractions proposed by Spirtas and his colleagues (see the Introduction) are applied to the annual mesotheliomas recorded in Finland in the 1990s (35 for men and 10-15 for women), about 30 should be workrelated. This number equals that of reported cases in 1993 - 1995 (table 2). Only a small fraction of the mesotheliomas in women is reported to be work-related. This finding is consistent with the results of a recent Finnish study (18). None of the 14 women with mesothelioma had occupational exposure to asbestos, whereas $51 \%$ of the 37 men had definite or probable occupational exposure.

The age-adjusted incidence of mesothelioma in men in Finland is in the lower range among industrialized countries. This low incidence is probably partly due to the fact that Finland, while currently a highly industrialized society, was not as industrialized as most other western societies in the 1950s and 1960s. Anthophyllite asbestos was quarried and widely used in Finland, and the mesothelioma risk of anthophyllite asbestos seems to be relatively low (19). This fact may also have contributed to the low incidence of mesothelioma in Finland. Exposure to crocidolite during shipyard work seems to be very common among Finnish mesothelioma patients, although many patients have had mixed exposure to various types of asbestos (20). Genetic factors also seem to play a role for mesothelioma (3). Recent studies in the United States and Great Britain found DNA sequences specific for Simian virus 40 (SV40) in the majority of mesothelioma tissue specimens from asbestosexposed persons, but not in the control samples $(4,21)$. The significance of these findings remains to be settled (22). 
Mesothelioma is considered to be a good indicator of the trend of the epidemic of asbestos-related diseases. A commonly used estimate for the number of asbestosrelated lung cancers is 2 times the number of asbestosrelated mesotheliomas. This estimate would yield about 60 asbestos-related lung cancers in men and less than 10 in women annually in the $1990 \mathrm{~s}$, while about 100 annual cases were reported in 1993-1995 (23). The high lung cancer:mesothelioma ratio in the occupational disease statistics may be partly attributed to the carcinogenic properties of Finnish anthophyllite asbestos $(19,24)$.

In conclusion the increasing trend in the incidence of mesothelioma has slowed in Finland. This development indicates that the number of asbestos-related mesotheliomas in 2010 will probably be less than the 100 annual cases estimated in the early $1990 \mathrm{~s}$. The reporting of occupational mesothelioma has reached a high level in the 1990s. It will be an important social challenge to maintain this high level of reporting as asbestos-related mesotheliomas will not disappear for many decades.

\section{Acknowledgments}

We thank Professor Lyly Teppo from the Finnish Cancer Registry for his valuable comments.

\section{References}

1. Spirtas R, Heinemann EF, Bernstein L, Beebe M, Keehn RJ, Stark A, et al. Malignant mesothelioma: attributable risk of asbestos exposure. Occup Environ Med 1994;51:804-11.

2. McDonald JC, McDonald AD. The epidemiology of mesothelioma in historical context. Eur Respir J 1996;9:1932 — 42.

3. Hirvonen A, Saarikoski ST, Linnainmaa K, Koskinen K, Husgafvel-Pursiainen K, Mattson K, et al. Gluthatione S-transferase and $\mathrm{n}$-acetyltransferase genotypes and asbestos-associated pulmonary disorders. JNCI 1996;88:1853-6.

4. Pepper C, Jasani B, Navabi H, Wynford-Thomas D, Gibbs AR. Simian virus 40 large $T$ antigen (SV40TLAg) primer specific DNA amplification in human pleural mesothelioma tissue. Thorax 1996;51:1074—6.

5. Damhuis RAM, Planteydt HT. Mesothelioma [letter]. Lancet 1995;345:1233-4.

6. De Vos Irvine H. Mesothelioma [letter]. Lancet 1995;345: 1233.

7. Price B. Analysis of current trends in United States mesothelioma incidence. Am J Epidemiol 1997;145:211—8.

8. Anonymous. Asbestos-linked cancer rates up less than predicted. JNCI 1992;84:560-2.
9. Peto J, Hodgson JT, Matthews FE, Jones JR. Continuing increase in mesothelioma mortality in Britain. Lancet 1995;345: $535-9$.

10. Huuskonen MS, Karjalainen A, Koskinen K, Tossavainen A, Rantanen J. Asbestisairauksien diagnostiikka ja seuranta [Diagnosis and surveillance of asbestos-related diseases]. Suomen Lääkäril 1993;48:988—95.

11. Andersson E, Toren K. Pleural mesotheliomas are underreported as occupational cancer in Sweden. Am J Ind Med 1995; 27:577-80.

12. Danø $\mathrm{H}$, Skov $\mathrm{T}$, Lynge $\mathrm{E}$. Underreporting of occupational cancers in Denmark. Scand J Work Environ Health 1996;22: 55-7.

13. Huuskonen MS, Koskinen K, Tossavainen A, Karjalainen A, Rinne JP, Rantanen J. Finnish Institute of Occupational Health asbestos program 1987-92. Am J Ind Med 1995;28:12342.

14. Teppo L, Pukkala E, Lehtonen M. Data quality and quality control of a population-based cancer registry: experience in Finland. Acta Oncol 1994;33:365-9.

15. Stayner LT, Dankovic DA, Lemen RA. Occupational exposure to chrysotile asbestos and cancer risk: a review of the amphibole hypothesis. Am J Public Health 1996;86:179-86.

16. World Health Organization (WHO). Environmental health criteria on chrysotile asbestos. Geneva: International Program on Chemical Safety, WHO. In press.

17. Karjalainen A, Huuskonen MS, Koskinen K, Mattson K, Riala $R$, Tossavainen A. Keuhkosyövän ja mesoteliooman ammattitautidiagnostiikka [Guidebook for exposure assessment and evaluation in the diagnostics of asbestos-related lung cancer and mesothelioma]. Helsinki: Finnish Institute of Occupational Health, 1992. English summary.

18. Tuomi T, Huuskonen MS, Virtamo M, Tossavainen A, Tammilehto L, Mattson K, et al. Relative risk of mesothelioma associated with different levels of exposure to asbestos. Scand J Work Environ Health 1991;17:404-8.

19. Meurman LO, Pukkala E, Hakama M. Cancer incidence among anthophyllite asbestos quarry workers in Finland. Occup Environ Med 1994;51:421-5.

20. Tuomi T. Fibrous minerals in the lungs of mesothelioma patients: comparison between data on SEM, TEM and personal interview information. Am J Ind Med 1992;21:155-62.

21. Carbone M, Pass HI, Rizzo P, Marinetti MR, Di Muzio M, Mew DJY, et al. Simian virus 40-like DNA sequences in human pleural mesothelioma. Oncogene 1994;9:781-90.

22. Strickler HD, Goedert JJ, Fleming M, Travis WD, Williams AE, Rabkin CS, et al. Simian virus 40 and pleural mesothelioma in humans. Cancer Epidemiol Biomarkers Prev 1996;5: 473-5.

23. Karjalainen A, Vasama M, Savela A, Jolanki R, Kauppinen T. Ammattitaudit 1995 [Occupational diseases 1995]. Helsinki: Finnish Institute of Occupational Health, 1996.

24. Karjalainen A, Anttila S, Vanhala E, Vainio H. Asbestos exposure and the risk of lung cancer in a general urban population. Scand J Work Environ Health 1994;20:243-50.

Received for publication: 4 February 1997 